\title{
Studies on Nutrient Release Pattern of Neem Fortified Cocoa Pod Husk Fertilizer in an Alfisol
}

\author{
Ogunlade Moses Ogunwole ${ }^{1}$, Gideon Olajire Adeoye ${ }^{2}$, Olajire Fagbola ${ }^{2}$ and Joseph Sunday Ogeh ${ }^{3}$ \\ ${ }^{1}$ Soil and Plant Nutrition Section, Cocoa Research Institute of Nigeria, P.M.B. 5244, Ibadan, Oyo State, \\ Nigeria, e-mail: mosesogunlade2@yahoo.com \\ ${ }^{2}$ Department of Agronomy, University of Ibadan, Ibadan, Oyo State, Nigeria, \\ e-mail: kutulolaola@yahoo.comandfagbola8@yahoo.co.uk \\ ${ }^{3}$ Department of Soil Science, Faculty of Agriculture, University of Benin, Benin City, Edo State, Nigeria, \\ e-mail: sogeh2@yahoo.com
}

Received 20 April 2012 / accepted 31 May 2012

\begin{abstract}
A laboratory experiment was carried out at Cocoa Research Institute of Nigeria, Ibadan to evaluate the nutrient release pattern of neem fortified cocoa pod husk developed for use as organic fertilizer materials. Cocoa Pod Husk $(\mathrm{CPH})$, Neem Leaf (NL), Neem Seed (NS), CPH + NL (90:10), CPH + NL (80:20), CPH + NS (90:10) and CPH + NS (80:20) were separately applied at the rate of $100 \mathrm{~kg} \mathrm{~N}^{-1}$ into $50 \mathrm{~g}$ soil placed in plastic cups. There were six sampling periods $(2,4,8,12,16$, and 20 weeks) after treatment application. Soil N (Kjeldahl), P (Bray 1), K (1 N $\mathrm{NH}_{4} \mathrm{OAc} \mathrm{pH} 7$ ) and $\mathrm{pH}$ (soil:water ratio 1:2) were determined at each sampling period. The result showed that the organic materials had significant effect in raising the $\mathrm{pH}$ of the soils compared to unamended soil. Neem fortified CPH significantly $(\mathrm{P}<0.05)$ increased nitrogen release higher than control at 8,12 and 16 weeks after application. Phosphorus release was significantly higher in soil treated with $\mathrm{CPH}$, NL, NS and neem fortified CPH than the control at 20 weeks after application. CPH and neem fortified CPH enhanced K release better than NL and NS applied separately across the incubation periods. Neem leaf and seed powder with higher $\mathrm{N}$ content than $\mathrm{CPH}$ is a precursor of $\mathrm{N}$ - release into the soil shortly after incorporation.
\end{abstract}

Keywords: Cocoa pod husk, neem fortified cocoa pod husk, neem seed and leaf, nutrient release, organic fertilizer

\section{INTRODUCTION}

Cocoa pod husk $(\mathrm{CPH})$ is one of the major wastes being generated annually in cocoa farms in Nigeria. Ayeni et al. (2008) showed that about 800,000 tonnes of cocoa pod husk are generated annually in Nigeria and are often wasted. Harvested cocoa pods are collected at a central location within the cocoa farm, where pods are broken, cocoa beans removed and husks discarded as waste and this is a potential source of pathogen like black pod disease since the pod harbours Phytophtora palmivora, the causal fungus of the disease. It was advised that husk be burnt into ash as a method of farm sanitation and for the control of these disease. On dry basis about $60 \%$ of cocoa (Theobroma cacao) pod is made up of the husk (Ogunlade et al. 2011). This implies that cocoa pod husk being generated in cocoa farms is even about $20 \%$ more than the dry cocoa beans normally realized. It therefore follows

J Trop Soils, Vol. 17, No. 3, 2012: 129-134

ISSN 0852-257X that if a farmer harvested $400 \mathrm{~kg}$ of dry cocoa beans per hectare from his farm he would have generated $600 \mathrm{~kg}$ of dry cocoa pod husk. Research efforts of turning waste into wealth have led to various attempt of finding diverse uses for cocoa pod husks. Cocoa pod husks are being used as fertilizers and soil amendment to suppress nematode population in cocoa soils (Ogunlade 2008, Ogunlade et al. 2009). Several studies have indicated that the efficiency of Nitrogen fertilizer particularly under tropical conditions hardly exceeds 50\% (Rayar and Bello 1990). This is due to the fact that Nitrogen is often lost through leaching especially from nitrate containing fertilizer (Rayar 1989). This situation warrants urgent need to increase the use efficiency of this nutrient amongst other nutrient elements when they are applied to the soil. With the escalating cost of fertilizers compounded with their unavailability during the growing season, it becomes increasingly important that an alternative affordable by farmers, with a view to achieving the maximum output per unit area of land becomes very necessary. 
Neem (Azardiracta indica L) products as a means of retarding nitrification have received some attention by researchers. Rayar and Bello (1990) used neem products to retard nitrification which resulted in marked increase in Nitrogen use efficiency. Moreover, there is dearth of information on the nutrient release pattern of $\mathrm{CPH}$ when used solely or in combination with other organic materials. Incorporation of high $\mathrm{C} / \mathrm{N}$ residues will deplete the soil supply of soluble nitrogen, causing plants to suffer from nitrogen deficiency (Allison 1973). The decay of organic materials can be delayed if sufficient nitrogen to support microbial growth is neither present in the material undergoing decomposition nor available in the soil solution (Brady 1990). No creature can multiply or grow on carbon alone. Organisms must also obtain sufficient nitrogen to synthesize nitrogen-containing cellular components, such as amino acids, enzymes, and DNA (Haynes 1986).

The objective of this study therefore was to evaluate nutrient release pattern of $\mathrm{CPH}$ incorporated into the soil solely or in combination with neem which has higher nitrogen contents.

\section{MATERIALS AND METHODS}

\section{Study Site and Preparation}

A laboratory experiment was conducted at the Cocoa Research Institute of Nigeria, Ibadan. A top soil collected from cocoa plots was sieved with $2 \mathrm{~mm}$ sieve and $50 \mathrm{~g}$ of the soil was weighed and filled into plastic cups of $50 \mathrm{~g}$ each for incubation studies. The organic fertilizer materials used for this experiment were collected fresh, dried and milled to pass through $4 \mathrm{~mm}$ sieve before application into the soils in plastic cups. They included the following: Cocoa Pod Husk (CPH), Neem Leaf powder (NL), Neem Seed powder (NS), $\mathrm{CPH}+\mathrm{NL}$ (90:10), CPH + NL (80:20), CPH + NS (90:10) and $\mathrm{CPH}+\mathrm{NS}$ (80:20). These organic materials in addition to a control (without organic material addition) gave eight treatments. The treatments were replicated three times to give a total of 24 treatments. There were a total of 144 plastic cups (i.e. 24 treatments $\times 6$ incubation periods) used for this experiment. The 144 plastic cups were arranged in a completely randomized design. Three plastic cups were withdrawn per treatment at the end of each incubation period for chemical analysis.

\section{Chemical Analysis}

The nutrient contents of each of the organic materials were determined using Nitric and
Perchloric acids wet digestion method by weighing $0.5 \mathrm{~g}$ of the material into a digestion beaker. To this was added $5 \mathrm{ml}$ of nitric and $2 \mathrm{ml}$ of perchloric acids. Then $2 \mathrm{ml}$ of sulphuric acid was also added to ensure the digest did not dry up under fume cupboard. The digest was transferred to a $100 \mathrm{ml}$ volumetric flask after cooling down and made up to mark with distilled water. From the digest $\mathrm{P}$ was determined using Vanado-Molybdate method colorimetrically; $\mathrm{K}$ and $\mathrm{Ca}$ were determined using flame photometer with appropriate filter while $\mathrm{Mg}$, $\mathrm{Cu}, \mathrm{Zn}, \mathrm{Mn}$ and $\mathrm{Fe}$ were determined on a Perkin Elmer Atomic Absorption Spectrophotometer.

Nitrogen in the samples was determined using Kjeldahl procedure. Each of the organic materials was separately applied to the soil in the plastic cups at the rate of $100 \mathrm{~kg} \mathrm{~N} \mathrm{ha}^{-1}$. Water was applied to each of the cups at $60 \%$ field capacity. Watering was done twice weekly. The nutrient (NPK) release pattern was assessed at 2- weeks' interval for the first one month and at one month interval for another four months to give six sampling / incubation periods.

Total Nitrogen mineralised was determined by micro-Kjedahl method. Available Phosphorus mineralised was extracted from the incubated samples using Bray P1 method. The available P in the filtrate was determined colorimetrically by molybdenum blue method. $\mathrm{K}$ mineralised was extracted with $1 \mathrm{~N} \mathrm{NH}_{4} \mathrm{OAc}$ at $\mathrm{pH}$ 7.0. The $\mathrm{K}$ in the filtrate was determined by flame photometer. The $\mathrm{pH}$ was determined in water (1:2 Soil: water ratio). The extract was shaken and a $\mathrm{pH}$ meter with glass electrode used to measure the $\mathrm{pH}$ as described by Jackson (1965).

\section{Statistical Analysis}

Data were statistically analyzed for analysis of variance (ANOVA) and Duncan Multiple Range Test (DMRT) at $\mathrm{P}<0.05$.

\section{RESULTS AND DISCUSSION}

The physical and chemical properties of the soil used in the experiment are presented in Table 1. The soil texture was sandy loam while the soil $\mathrm{pH}$ was slightly acidic. The soil N, P and K contents were less than the critical values established as $\mathrm{N}=$ $0.9 \mathrm{~g} \mathrm{~kg}^{-1}, \mathrm{P}=10 \mathrm{mg} \mathrm{kg}^{-1}$ and $\mathrm{K}=0.3 \mathrm{cmol}(+) \mathrm{kg}^{-1}$ for cocoa (Egbe et al. 1989). The nutrient content of the organic materials used in this experiment are presented in Table 2. The nitrogen contents of NL and NS was more than twice that of CPH. The phosphorus contents were in the order of NS $>\mathrm{NL}$ $>\mathrm{CPH}$. The potassium and calcium contents of $\mathrm{CPH}$ 
Table 1. Some physical and chemical properties of the soil used.

\begin{tabular}{|c|c|}
\hline Soil Properties & Values \\
\hline $\mathrm{pH}$ & 6.00 \\
\hline Organic carbon $\left(\mathrm{g} \mathrm{kg}^{-1}\right)$ & 10.10 \\
\hline $\mathrm{N}\left(\mathrm{g} \mathrm{kg}^{-1}\right)$ & 0.77 \\
\hline $\mathrm{P}\left(\mathrm{mg} \mathrm{kg}^{-1}\right)$ & 4.11 \\
\hline $\mathrm{K}\left(\mathrm{cmol}(+) \mathrm{kg}^{-1}\right)$ & 0.22 \\
\hline $\mathrm{Ca}\left(\mathrm{cmol}(+) \mathrm{kg}^{-1}\right)$ & 4.45 \\
\hline $\operatorname{Mg}\left(\mathrm{cmol}(+) \mathrm{kg}^{-1}\right)$ & 1.23 \\
\hline $\mathrm{Na}\left(\mathrm{cmol}(+) \mathrm{kg}^{-1}\right)$ & 0.13 \\
\hline Exchangeable Acidity $\left(\mathrm{cmol}(+) \mathrm{kg}^{-1}\right)$ & 0.73 \\
\hline $\mathrm{Zn}\left(\mathrm{mg} \mathrm{kg}^{-1}\right)$ & 5.56 \\
\hline $\mathrm{Cu}\left(\mathrm{mg} \mathrm{kg}^{-1}\right.$ & 6.40 \\
\hline $\operatorname{Mn}\left(m g \mathrm{~kg}^{-1}\right)$ & 18.90 \\
\hline $\mathrm{Fe}\left(\mathrm{mg} \mathrm{kg}^{-1}\right)$ & 5.83 \\
\hline $\mathrm{B}\left(\mathrm{mg} \mathrm{kg}^{-1}\right)$ & 0.37 \\
\hline Sand $(\%)$ & 60 \\
\hline Silt $(\%)$ & 24 \\
\hline Clay $(\%)$ & 16 \\
\hline Texture & Sandy Loam \\
\hline
\end{tabular}

were higher than those of NL and NS. Of all the three organic materials, $\mathrm{Mg}$ content of NL was the highest. The high $\mathrm{K}$ content of $\mathrm{CPH}$ has been reported and this made $\mathrm{CPH}$ a good source of $\mathrm{K}$ supply for high $\mathrm{K}$ demanding crops (Ipinmoroti 1997; Adeoye et al. 2001). The Ca content was highest in $\mathrm{CPH}$. Oguntuga (1975) gave similar report on chemical constituents of cocoa pod husks. Neem leaf and NS had similar Ca contents.

The zinc and iron contents of the organic materials were in the order of NS $>\mathrm{NL}>\mathrm{CPH}$ while manganese and copper contents were in the order of $\mathrm{CPH}>\mathrm{NL}>\mathrm{NS}$. The Boron content of NS was $4.0 \mathrm{mg} \mathrm{kg}^{-1}$ compared to $\mathrm{CPH}$ and NL with boron contents of 1.8 and $1.7 \mathrm{mg} \mathrm{kg}^{-1}$, respectively.

\section{Soil nitrogen $(\mathbf{N})$}

Soil nitrogen mineralization $\left(0.27 \mathrm{~g} \mathrm{~kg}^{-1}\right)$ was significantly $(\mathrm{P}<0.05)$ reduced in the $\mathrm{CPH}$ treatment when compared with the control $(0.57 \mathrm{~g}$ $\mathrm{kg}^{-1}$ ) at two weeks after incubation (Table 3). This might be due to immobilization of nitrogen released from soil organic matter. Reports have also shown that when low nitrogen crop residues are buried in the soil, nitrogen is immobilised, but high nitrogen containing residues improve $\mathrm{N}$ mineralization (Ladd 1981; Azam et al. 1985; Smith and Sharply 1990). Minimum residue $\mathrm{N}$ contents of 1.5 to $1.7 \%(\mathrm{C} / \mathrm{N}$ ratios of 25 to 30) have been suggested to supply the need of soil microbes during crop residues decomposition (Allison 1973; Smith and Eliott 1990). The results obtained in this study corroborate this trend. The higher nitrogen released in soil treated with $\mathrm{CPH}$ as from eight weeks after incubation compared to the control suggests remineralization of nitrogen immobilized at the start of incubation which has been retained in organic forms of $\mathrm{N}$ biomass and liberated thereafter when decomposition progressed. At $16 \mathrm{WAI}$, the $\mathrm{N}$ mineralized in the soil treated with NL, NS, CPH and neem-fortified $\mathrm{CPH}$ were significantly ( $\mathrm{P}<$ 0.05) higher than those of control soil. Fortification of $\mathrm{CPH}$ with neem is a release precursor for nitrogen. This was similar to the report of Ogunlade et al. (2006) when pacesetter grade B organic fertilizer was fortified with neem leaf powder.

Table 2. Nutrient contents of the organic materials.

\begin{tabular}{lrrr}
\hline Nutrient contents & $\mathrm{CPH}$ & $\mathrm{NL}$ & $\mathrm{N}$ \\
\hline $\mathrm{N}\left(\mathrm{g} \mathrm{kg}^{-1}\right)$ & 11.2 & 26.7 & 25.0 \\
Organic carbon $\left(\mathrm{g} \mathrm{kg}^{-1}\right)$ & 236.2 & 120.1 & 144.6 \\
$\mathrm{C} / \mathrm{N}$ & 21.1 & 4.5 & 5.8 \\
$\mathrm{P}\left(\mathrm{g} \mathrm{kg}^{-1}\right)$ & 1.4 & 1.9 & 2.1 \\
$\mathrm{~K}\left(\mathrm{~g} \mathrm{~kg}^{-1}\right)$ & 38.6 & 24.0 & 21.0 \\
$\mathrm{Ca}\left(\mathrm{g} \mathrm{kg}^{-1}\right)$ & 3.1 & 1.8 & 1.7 \\
$\mathrm{Mg}\left(\mathrm{g} \mathrm{kg}^{-1}\right)$ & 1.7 & 2.4 & 1.5 \\
$\mathrm{Zn}\left(\mathrm{mg} \mathrm{kg}^{-1}\right)$ & 25.0 & 50.0 & 51.0 \\
$\mathrm{Mn}\left(\mathrm{mg} \mathrm{kg}^{-1}\right)$ & 34.0 & 29.0 & 25.0 \\
$\mathrm{Fe}\left(\mathrm{mg} \mathrm{kg}^{-1}\right)$ & 64.0 & 69.0 & 70.0 \\
$\mathrm{Cu}\left(\mathrm{mg} \mathrm{kg}^{-1}\right)$ & 28.0 & 25.0 & 23.0 \\
$\mathrm{~B}\left(\mathrm{mg} \mathrm{kg}^{-1}\right)$ & 1.8 & 1.7 & 4.0 \\
\hline
\end{tabular}

$\mathrm{CPH}=$ Cocoa Pod Husk, NL= Neem Leaf, and NS $=$ Neem Seed. 
Table 3. Soil $\mathrm{N}$ concentrations as influenced by organic materials during period of incubation.

\begin{tabular}{lllllll}
\hline \multirow{2}{*}{ Treatment } & \multicolumn{7}{c}{ Weeks After Incubation (WAI) } \\
\cline { 2 - 7 } & 2 & 4 & 8 & 12 & 16 & 20 \\
\hline & $0.27 \mathrm{~d}$ & $0.33 \mathrm{c}$ & $0.47 \mathrm{c}$ & $0.23 \mathrm{bc}$ & $0.50 \mathrm{abc}$ & $0.17 \mathrm{bc}$ \\
$\mathrm{CPH}$ & $0.70 \mathrm{a}$ & $0.67 \mathrm{ab}$ & $0.77 \mathrm{ab}$ & $0.27 \mathrm{~b}$ & $0.50 \mathrm{abc}$ & $0.27 \mathrm{ab}$ \\
$\mathrm{NL}$ & $0.60 \mathrm{ab}$ & $0.67 \mathrm{ab}$ & $0.67 \mathrm{ab}$ & $0.38 \mathrm{ab}$ & $0.57 \mathrm{ab}$ & $0.17 \mathrm{bc}$ \\
$\mathrm{NS}$ & $0.43 \mathrm{c}$ & $0.67 \mathrm{ab}$ & $0.73 \mathrm{ab}$ & $0.3 \mathrm{ab}$ & $0.43 \mathrm{bc}$ & $0.17 \mathrm{bc}$ \\
$\mathrm{CPH}+\mathrm{NL}(90: 10)$ & $0.47 \mathrm{bc}$ & $0.76 \mathrm{a}$ & $0.70 \mathrm{ab}$ & $0.40 \mathrm{a}$ & $0.60 \mathrm{a}$ & $0.33 \mathrm{a}$ \\
$\mathrm{CPH}+\mathrm{NL}(80: 20)$ & $0.50 \mathrm{c}$ & $0.70 \mathrm{a}$ & $0.63 \mathrm{~b}$ & $0.30 \mathrm{ab}$ & $0.40 \mathrm{c}$ & $0.27 \mathrm{ab}$ \\
$\mathrm{CPH}+\mathrm{NS}(90: 10)$ & $0.50 \mathrm{c}$ & $0.73 \mathrm{a}$ & $0.80 \mathrm{a}$ & $0.43 \mathrm{a}$ & $0.47 \mathrm{abc}$ & $0.30 \mathrm{ab}$ \\
$\mathrm{CPH}+\mathrm{NS}(80: 20)$ & $0.57 \mathrm{abc}$ & $0.53 \mathrm{~b}$ & $0.33 \mathrm{c}$ & $0.13 \mathrm{c}$ & $0.23 \mathrm{~d}$ & $0.10 \mathrm{c}$ \\
Control & &
\end{tabular}

$\mathrm{CPH}=$ Cocoa Pod Husk, NL= Neem Leaf, and NS= Neem Seed. Means in the same column followed by the same letters are not significantly different by Duncan Multiple Range Test (DMRT) at $\mathrm{P}<0.05$.

\section{Soil Phosphorus}

Phosphorus released was enhanced by Neem leaf and was significantly higher than all other organic materials at 2 and 4 WAI (Table 4). Generally, the organic materials released higher amount of $\mathrm{P}$ in comparison to control as from 12 WAI. Neem leaf-fortified CPH gave higher P release than neem seed-fortified $\mathrm{CPH}$ as from 12 WAI up till 20 WAI. The P released by CPH $(6.38$ $\mathrm{mg} \mathrm{kg}^{-1}$ soil) and $\mathrm{CPH}+\mathrm{NL}(80: 20)(6.39 \mathrm{mg}$ $\mathrm{kg}^{-1}$ soil $)$ at 20 WAI was significantly $(\mathrm{P}<0.05)$ higher than $P$ released by other organic materials. Though the P content of NS was higher, however, NL treated soil enhanced phosphorus release better than all other treatments including control.

\section{Soil Potassium}

Amount of potassium released from all the organic materials was significantly $(\mathrm{P}<0.05)$ higher in comparison with the control at 2, 8, 16 and 20 WAI (Table 5). CPH applied alone and neem fortified $\mathrm{CPH}$ significantly $(\mathrm{P}<0.05)$ enhanced $\mathrm{K}$ release better than neem leaf and neem seed powder applied separately at 2, 4 and 16 WAI. At 20 WAI, CPH + NL (90:10) significantly released more $\mathrm{K}$ than all the other organic material treatments.

$\mathrm{K}$ release by soil treated with $\mathrm{CPH}+\mathrm{NS}$ (90:10) was not significantly different from that of $\mathrm{CPH}+\mathrm{NS}$ (80:20) across all the incubation periods except at $4 \mathrm{WAI}$ where $\mathrm{CPH}+\mathrm{NS}(80: 20)$ released was significantly $(\mathrm{P}<0.05)$ higher $\mathrm{K}$

Table 4. Soil $\mathrm{P}$ concentrations as influenced by organic materials during period of Incubation.

\begin{tabular}{lllllll}
\hline \multirow{2}{*}{ Treatment } & \multicolumn{6}{c}{ Weeks After Incubation (WAI) } \\
\cline { 2 - 7 } & 2 & 4 & 8 & 12 & 16 & 20 \\
\hline & $4.90 \mathrm{~b}$ & $4.12 \mathrm{~b}$ & $6.05 \mathrm{c}$ & $5.82 \mathrm{a}-\mathrm{c}$ & $5.71 \mathrm{ab}$ & $6.38 \mathrm{a}$ \\
$\mathrm{CPH}$ & $7.28 \mathrm{a}$ & $5.37 \mathrm{a}$ & $7.15 \mathrm{a}$ & $6.28 \mathrm{a}$ & $6.19 \mathrm{a}$ & $6.17 \mathrm{~b}$ \\
$\mathrm{NL}$ & $5.16 \mathrm{~b}$ & $3.13 \mathrm{~d}$ & $4.99 \mathrm{~d}$ & $5.96 \mathrm{ab}$ & $5.79 \mathrm{ab}$ & $4.84 \mathrm{~d}$ \\
$\mathrm{NS}$ & $4.66 \mathrm{~b}$ & $2.90 \mathrm{~d}$ & $6.79 \mathrm{ab}$ & $6.14 \mathrm{a}$ & $5.99 \mathrm{a}$ & $5.87 \mathrm{c}$ \\
$\mathrm{CPH}+\mathrm{NL}(90: 10)$ & $5.27 \mathrm{~b}$ & $3.85 \mathrm{bc}$ & $6.91 \mathrm{ab}$ & $6.30 \mathrm{a}$ & $6.16 \mathrm{a}$ & $6.39 \mathrm{a}$ \\
$\mathrm{CPH}+\mathrm{NL}(80: 20)$ & $4.83 \mathrm{~b}$ & $3.89 \mathrm{bc}$ & $6.22 \mathrm{bc}$ & $5.61 \mathrm{bc}$ & $5.43 \mathrm{bc}$ & $4.36 \mathrm{e}$ \\
$\mathrm{CPH}+\mathrm{NS}(90: 10)$ & $5.02 \mathrm{~b}$ & $3.38 \mathrm{~cd}$ & $3.90 \mathrm{e}$ & $5.35 \mathrm{c}$ & $5.21 \mathrm{c}$ & $3.31 \mathrm{f}$ \\
$\mathrm{CPH}+\mathrm{NS}(80: 20)$ & $3.89 \mathrm{~b}$ & $2.84 \mathrm{~d}$ & $3.32 \mathrm{e}$ & $4.83 \mathrm{~d}$ & $4.52 \mathrm{~d}$ & $3.08 \mathrm{~g}$ \\
Control & & &
\end{tabular}

$\mathrm{CPH}=$ Cocoa Pod Husk, NL= Neem Leaf, and NS = Neem Seed. Means in the same column followed by the same letters are not significantly different by Duncan Multiple Range Test (DMRT) at $\mathrm{P}<0.05$. 
Table 5. Soil K concentrations as influenced by organic materials during the period of incubation.

\begin{tabular}{lcccccc}
\hline \multirow{2}{*}{ Treatment } & \multicolumn{6}{c}{ Weeks After Incubation (WAI) } \\
\cline { 2 - 7 } & 2 & 4 & 8 & 12 & 16 & 20 \\
\hline & $0.30 \mathrm{~b}$ & $0.25 \mathrm{c}$ & $0.36 \mathrm{~b}$ & $0.33 \mathrm{a}$ & $0.40 \mathrm{a}$ & $0.31 \mathrm{~d}$ \\
$\mathrm{CPH}$ & $0.24 \mathrm{c}$ & $0.16 \mathrm{~d}$ & $0.29 \mathrm{c}$ & $0.26 \mathrm{~b}$ & $0.32 \mathrm{~b}$ & $0.30 \mathrm{~d}$ \\
$\mathrm{NL}$ & $0.20 \mathrm{~d}$ & $0.10 \mathrm{e}$ & $0.24 \mathrm{~d}$ & $0.21 \mathrm{c}$ & $0.26 \mathrm{c}$ & $0.22 \mathrm{e}$ \\
$\mathrm{NS}$ & $0.32 \mathrm{~b}$ & $0.34 \mathrm{a}$ & $0.49 \mathrm{a}$ & $0.35 \mathrm{a}$ & $0.41 \mathrm{a}$ & $0.49 \mathrm{a}$ \\
$\mathrm{CPH}+\mathrm{NL}(90: 10)$ & $0.38 \mathrm{a}$ & $0.32 \mathrm{ab}$ & $0.36 \mathrm{~b}$ & $0.26 \mathrm{~b}$ & $0.42 \mathrm{a}$ & $0.45 \mathrm{~b}$ \\
$\mathrm{CPH}+\mathrm{NL}(80: 20)$ & $0.30 \mathrm{~b}$ & $0.27 \mathrm{c}$ & $0.33 \mathrm{bc}$ & $0.32 \mathrm{a}$ & $0.40 \mathrm{a}$ & $0.34 \mathrm{c}$ \\
$\mathrm{CPH}+\mathrm{NS}(90: 10)$ & $0.31 \mathrm{~b}$ & $0.30 \mathrm{~b}$ & $0.32 \mathrm{bc}$ & $0.34 \mathrm{a}$ & $0.39 \mathrm{a}$ & $0.32 \mathrm{~cd}$ \\
CPH+NS(80:20) & $0.13 \mathrm{e}$ & $0.12 \mathrm{e}$ & $0.15 \mathrm{e}$ & $0.28 \mathrm{~b}$ & $0.19 \mathrm{~d}$ & $0.14 \mathrm{f}$ \\
Control & & & & & &
\end{tabular}

$\mathrm{CPH}=$ Cocoa Pod Husk, NL= Neem Leaf, and NS= Neem Seed. Means in the same column followed by the same letters are not significantly different by Duncan Multiple Range Test (DMRT) at $\mathrm{P}<0.05$.

(0.30 $\mathrm{cmol}(+) \mathrm{kg}^{-1}$ soil) than CPH+NS $(90: 10)$ which released $0.27 \mathrm{cmol}(+) \mathrm{kg}^{-1}$ soil. At 8,12 and $20 \mathrm{WAI}, \mathrm{CPH}+\mathrm{NL}(90: 10)$ significantly $(\mathrm{P}$ $<0.05)$ released K more than CPH + NL (80:20). The higher $\mathrm{K}$ release observed in soils treated with CPH was probably due to higher K contents of $\mathrm{CPH}$. The sharp increase at 16 WAI may be due to greater decomposition that must have taken place.

\section{Soil pH}

$\mathrm{pH}$ of the soils treated with the different organic fertilizers were significantly increased compared to the control as from 4 WAI except at 12 WAI when soil treated with neem seed and the control had $\mathrm{pH}$ values that were not significantly different (Table 6). NL significantly enhanced $\mathrm{pH}$ values better than NS across the incubation periods. However, the effect of CPH fortified with neem leaf powder and neem seed powder on $\mathrm{pH}$ did not follow this trend. $\mathrm{CPH}+\mathrm{NL}$ (90:10) and CPH + NL (80:20) treated soils had significantly higher $\mathrm{pH}$ values than all other fertilizer materials at 20 WAI. The higher soil $\mathrm{pH}$ of the amended soil than the control treatment at each period of $\mathrm{pH}$ determination was probably due to the supply of basic cations into the system by the mineralization of the organic materials. Obatolu (1991), Oladokun 1986 and Lal et al. (1980) reported similar trend.

\section{CONCLUSIONS}

Neem-fortified Cocoa Pod Husk enhanced Nitrogen mineralization better than non-fortified Cocoa Pod Husk during the first eight weeks of incubation. Neem leaf and seed powder with higher $\mathrm{N}$ content than Cocoa Pod Husk is a precursor of

Table 6. Soil $\mathrm{pH}$ as influenced by the organic materials during the period of incubation.

\begin{tabular}{lcccccc}
\hline \multirow{2}{*}{ Treatment } & \multicolumn{6}{c}{ Weeks After Incubation (WAI) } \\
\cline { 2 - 7 } & 2 & 4 & 8 & 12 & 16 & 20 \\
\hline $\mathrm{CPH}$ & $6.30 \mathrm{a}$ & $6.14 \mathrm{e}$ & $6.32 \mathrm{e}$ & $6.26 \mathrm{~d}$ & $6.26 \mathrm{c}$ & $5.88 \mathrm{c}$ \\
$\mathrm{NL}$ & $6.15 \mathrm{c}$ & $6.15 \mathrm{e}$ & $6.56 \mathrm{c}$ & $6.32 \mathrm{c}$ & $6.32 \mathrm{bc}$ & $5.90 \mathrm{c}$ \\
$\mathrm{NS}$ & $5.66 \mathrm{e}$ & $5.95 \mathrm{f}$ & $6.32 \mathrm{e}$ & $6.00 \mathrm{e}$ & $6.13 \mathrm{~d}$ & $5.73 \mathrm{~d}$ \\
$\mathrm{CPH}+\mathrm{NL}(90: 10)$ & $6.52 \mathrm{a}$ & $6.26 \mathrm{c}$ & $6.51 \mathrm{~d}$ & $6.40 \mathrm{~b}$ & $6.41 \mathrm{~b}$ & $6.02 \mathrm{a}$ \\
$\mathrm{CPH}+\mathrm{NL}(80: 20)$ & $6.51 \mathrm{a}$ & $6.46 \mathrm{~b}$ & $6.60 \mathrm{~b}$ & $6.41 \mathrm{~b}$ & $6.40 \mathrm{~b}$ & $6.02 \mathrm{a}$ \\
$\mathrm{CPH}+\mathrm{NS}(90: 10)$ & $6.23 \mathrm{bc}$ & $6.50 \mathrm{a}$ & $6.65 \mathrm{a}$ & $6.54 \mathrm{a}$ & $6.55 \mathrm{a}$ & $5.88 \mathrm{c}$ \\
$\mathrm{CPH}+\mathrm{NS}(80: 20)$ & $6.18 \mathrm{c}$ & $6.22 \mathrm{~d}$ & $6.29 \mathrm{f}$ & $6.26 \mathrm{~d}$ & $6.25 \mathrm{c}$ & $5.98 \mathrm{~b}$ \\
Control & $5.85 \mathrm{~d}$ & $5.72 \mathrm{~h}$ & $5.61 \mathrm{~g}$ & $5.93 \mathrm{e}$ & $5.94 \mathrm{e}$ & $5.54 \mathrm{e}$ \\
\hline
\end{tabular}

$\mathrm{CPH}=$ Cocoa Pod Husk, NL= Neem Leaf, and NS= Neem Seed. Means in the same column followed by the same letters are not significantly different by Duncan Multiple Range Test (DMRT) at $\mathrm{P}<0.05$. 
$\mathrm{N}$ - release into the soil shortly after incorporation. Findings from this study point to the fact that neem products could effectively be used to retard nitrification resulting in the increase of nitrogen release into the soil. Phosphorus and Potassium release into the soil during the period of incubation have shown that the release of these nutrients can enhance the productivity of the soil for crop growth and yield.

\section{REFERENCES}

Adeoye GO, MKC Shridhar and RR Ipinmoroti. 2001. Potassium recovery from farm wastes for crop growth. Commun Soils Plant Anal 32 (15 \& 16): 2347-2358.

Allison FE. 1973. Soil organic matter and its role in crop production. Elsivier scientific Publ. Co., Amsterdam, The Netherlands. pp. 247- 251.

Ayeni LS, MT Adetunji, SO Ojeniyi, BS Ewulo and AJ Adeyemo. 2008. Comparative and cumulative effect of cocoa pod husk ash and poultry manure on soil and maize nutrient contents and yield. AmEurasian J Sustain Agric 2 (1): 92-97.

Azam F, KA Malik and MI Sajjad. 1985. Transformations in soil and availability to plants of ${ }^{15} \mathrm{~N}$ applied as inorganic and legume residues. Plant soil 86: 3-13.

Brady NC. 1990. The Nature and Properties of Soils, $10^{\text {th }}$ ed. New York: Macmillan publishing Company p. 881.

Egbe NE, EA Ayodele and CR Obatolu. 1989. Soils and Nutrition of Cocoa, Coffee, Kola, Cashew and Tea. In Progress in tree crop research in Nigeria. $2^{\text {nd }} \mathrm{Ed}$. CRIN, Ibadan, pp 27-38.

Haynes RJ. 1986. The decomposition process. Mineralization, immobilization, humus formation and degradation. In: RJ Haynes (ed.), Minerals Nitrogen in the plant - soil system. (New York: Academic Press, pp. 88-106.

Ipinmoroti RR. 1997. A study on the recovery of mineral nutrients from common farm wastes and their effects on crop growth. M.Sc project University of Ibadan, Nigeria p. 81.

Jackson ML. 1965. ASA Monograph No.9. Methods of Soil Analysis. 45p.

Ladd JN. 1981. The use of $15 \mathrm{~N}$ in following organic matter turnover with specific reference to rotation systems. Plant Soil 58: 407-411.
Lal R, DD Vleescheauwer and RM Ngoje. 1980. Changes in properties of a newly cleared tropical Alfisol as affected by mulching. Soil Sci Soc Am J 44: 827-833.

Obatolu CR. 1991. Growth and nutrient uptake of coffee (Coffea spp.) seedlings grown on different organic materials. [Ph.D Thesis]. University of Ibadan, Ibadan. 276 pp.

Ogunlade MO, GO Adeoye and AO Fademi. 2009. Nematode populations and cocoa seedling establishment as influenced by cocoa pod husk fertilizer. Proceedings of the $43^{\text {rd }}$ Annual Conference of the Agricultural Society of Nigeria, Abuja, pp. 1029-1032.

Ogunlade MO, GO Adeoye, RR Ipinmoroti, OS Ibiremo and CI Iloyanomon. 2006. Comparative effect of organic and NPK fertilizer on the growth and nutrient uptake of cocoa seedlings. Nigeria J Soil Sci 16:121-125.

Ogunlade MO, KA Oluyole, AO Dada and EA Adeyemi. 2011. Determination of the quantity of cocoa pod husk being generated in cocoa plantations in Nigeria. Obeche J 29 (1): 246-249.

Ogunlade MO. 2008 Seedling establishment under old cocoa plantation using neem- fortified cocoa pod husk fertilizer at Ibadan and Owena, western Nigeria. [Ph.D Thesis]. University of Ibadan, Ibadan.

Ogutuga DBA. 1975. Some physical and chemical characteristics of the pod husk of F3 Amazon, Trinitario and Amelonado Cacao. Nigeria J Agric Sci 8: 115-120.

Oladokun MAO. 1986. Use of cocoa pod husk as fertilizers for maize production. Nigeria J Agron 1 (3): 103-109.

Rayar AJ and DK Bello. 1990. Effect of Urea treated with neem seed crush on yield and Nitrogen use efficiency in wheat. In: AJ Rayar (ed). Wheat in Nigeria: Production, Processing and Utilization. LCRI, IAR and Unimaid.

Rayar AJ. 1989. Neem seed crushed treated Urea for increased Nitrogen Use Efficiency in a semi-arid soil of Northeastern Nigeria. Nigeria J Soil Sci 9: 72-84.

Smith JL and LF Elliott. 1990. Tillage and residue management effects on soil organic matter dynamics in semi arid regions. In: RP Singh, JF Parr and BA Stewart (eds). Advances in Soil Science. American Society of Agronomy. Madison, Wisconsin. 13, pp. 69-85.

Smith SJ and AN Sharpley. 1990. Soil nitrogen mineralization in the presence of surface and incorporated crop residue. Agron J 82: 112-116. 